\title{
Presence of antinutritional factors in legumes
}

\section{Presencia de factores antinutricionales en legumbres}

\author{
MARCOS-MÉNDEZ, Dora Alicia $\dagger^{1}$, CANSECO-NAVA, Helena ${ }^{2}$, OLIART-ROS, Rosa María ${ }^{1}$ and \\ RAMÍREZ-HIGUERA, Abril ${ }^{1 *}$
}

${ }^{1}$ Unidad de Investigación y Desarrollo de Alimentos, Tecnológico Nacional de México/ I.T. Veracruz. Av. Miguel Ángel de Quevedo No. 2779, Col. Formando hogar. C.P. 91987. Veracruz, Ver., México.

${ }^{2}$ Facultad de Nutrición Universidad Veracruzana. Médicos y Odontólogos S/N Unidad del Bosque Xalapa. C.P. 91017. Xalapa-Enríquez, Ver., México.

ID $1^{\text {st }}$ Author: Dora Alicia, Marcos-Méndez / ORC ID: 0000-0002-5662-5478, CVU CONACYT ID: 1027248

ID $1^{\text {st }}$ Co-author: Helena, Canseco-Nava / ORC ID: 0000-0002-9381-0517

ID $2^{\text {nd }}$ Co-author: Rosa María, Oliart-Ros / ORC ID: 0000-0003-1204-8792, CVU CONACYT ID: 26058

ID $3^{\text {rd }}$ Co-author: Abril, Ramírez-Higuera / ORC ID: 0000-0002-1430-2689, CVU CONACYT ID: 242658

DOI: $10.35429 /$ JOIE.2021.17.5.6.13

Recibido 19 de July, 2021; Aceptado 30 de December, 2021

\begin{abstract}
Legumes are one of the main sources of vegetable protein, and it has also been shown that, after consumption, beneficial effects can be obtained for human health, since they can help reduce blood glucose levels, as they are considered a low glycemic index food, promote bone health, and contain bioactive compounds with different biological activities such as hypotensive or hypocholesterolemic, among others. This group of foods are considered complete foods since they contain proteins, carbohydrates, minerals, vitamins, among other nutritional components; however, they also have antinutritional factors (ANF), which are defined as non-fibrous natural substances that can cause a negative effect on the nutritional value of some foods, as well as on health since they hinder or inhibit the assimilation of some nutrients. For this reason, it is of great importance to apply processing methods to reduce or eliminate the presence of these ANF in legumes.
\end{abstract}

\section{Legumes, Antinutritional factors, Processing} methods

\begin{abstract}
Resumen
Las legumbres son una de las principales fuentes de proteína de origen vegetal; además se ha demostrado que, tras su consumo, se pueden obtener efectos benéficos para la salud humana, debido a que ayudan a reducir los niveles de glucosa en sangre, al ser consideradas un alimento de bajo índice glicémico, promueven la salud ósea, y contienen compuestos bioactivos con distintas actividades biológicas como hipotensora o hipocolesterolémica, entre otras. Este grupo de alimentos se consideran alimentos completos ya que contienen proteínas, carbohidratos, minerales, vitaminas, entre otros componentes nutricionales; sin embargo, también presentan en su composición factores antinutricionales (FAN), que se definen como aquellas sustancias naturales no fibrosas que pueden causar un efecto negativo en el valor nutricional de algunos alimentos, así como en la salud, ya que dificultan o inhiben la asimilación de algunos nutrientes. Es por esto que resulta de gran importancia utilizar métodos de procesamiento adecuados para reducir o eliminar los FAN presentes en las legumbres.
\end{abstract}

Legumbres, Factores antinutricionales, Métodos de procesamiento

Citation: MARCOS-MÉNDEZ, Dora Alicia, CANSECO-NAVA, Helena, OLIART-ROS, Rosa María and RAMÍREZHIGUERA, Abril. Presence of antinutritional factors in legumes. Journal of Innovative Engineering. 2021. 5-17: 6-13

\footnotetext{
*Correspondence to Author (e-mail: abril.rh@ veracruz.tecnm.mx)

$\uparrow$ Researcher contributing as first Author.
} 


\section{Introduction}

Legumes are considered complete foods since they contain proteins, carbohydrates, minerals, vitamins, among other nutritional components (Elizalde, et al., 2009). They are an excellent complementary food for infants and young children to meet their daily energy needs and are also very important in women of childbearing age (FAO, 2016).

However, legumes have antinutritional factors (ANF) in their composition (Elizalde, et al., 2009); examples are tannins, phytic acid, trypsin inhibitors, and flatulence-causing oligosaccharides (Khattab and Arntfield, 2009). ANF are defined as non-fibrous natural substances that are generated by the secondary metabolism of plants as a defense mechanism, which can cause a negative effect on the nutritional value of this food group, as well as on health, since they hinder or inhibit the assimilation of some nutrients (Elizalde, et al., 2009).

Among the main ANF present in legumes are tannins, which are versatile, astringent and water-soluble phenolic compounds that reduce the bioavailability of food in the intestine (Idate, et al., 2021); saponins, which are compounds that have a complex structure made up of a hydrophobic steroidal nucleus and a hydrophilic part made up of monosaccharide units. Saponins cannot be absorbed in the intestine, thus affecting the absorption of zinc and iron (Elizalde, et al., 2009).

Another ANF are phytates, present in small amounts in legumes and other food groups; due to their negative charge they bind to minerals such as iron, zinc, calcium, and magnesium, giving rise to an insoluble complex (Idate, et al., 2021). Phytates have been widely shown to inhibit the biological functions of trace elements (calcium, magnesium, zinc, iron, etc.), food proteins, and digestive enzymes, causing potential digestive problems. (Kumar, et al., 2010, Muzquiz, et al., 2012).

Protease inhibitors are thermolabile compounds that cause alterations in the digestion of proteins (Elizalde, et al., 2009 Lectins can bind to carbohydrate chains of glycoproteins and glycolipids,both glycoconjugates bound to the glycocalyx membrane and free glycoconjugates in mucus (Lagarda, et al., 2017).
These reduce the surface of the villi, which diminishes the gastric secretion for the absorption of nutrients (Idate, et al., 2021).

There are different processing methods and treatments that improve the nutritional quality of legumes by reducing the content of ANF. These methods are adapted to each specific legume; some examples are milling, soaking, cooking, germination, and dehulling.

\section{Legumes}

Legumes (Leguminosae family) are plants, which are a fruit formed by a pod that encloses a seed or a row of seeds inside, which are consumed dry. Legumes usually contain about twice the amount of protein found in whole grain cereals, so they are an excellent complementary food for infants and young children to meet their daily energy needs (FAO, 2016).

When combined with foods rich in vitamin $\mathrm{C}$, the high iron content of legumes can make them an important food to replenish iron stores, especially for women of childbearing age, who are more vulnerable to iron deficiency anemia (FAO, 2016).

In Mexico, about 1.93 million hectares are allocated to the cultivation of legumes: beans ( $91.7 \%$ of the area), chickpea $(6.4 \%)$, broad bean $(1.4 \%)$, lentils $(0.4 \%)$, and peas ( 0.1 percent); being $12.3 \%$ of the area destined to cyclical crops in the country.

The most consumed legume is bean, with more than 70 varieties (black, yellow, white, purple, bay, pinto, and mottled) (Ministry of Agriculture and Rural Development, 2015). It has been demonstrated that including legumes in the human diet is beneficial, Table 1 mentions some examples of these vantages (FAO, 2016):

Healthy benefits Mechanism of action

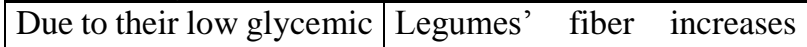
index, low-fat content, satiety and helps stabilize and high fiber content, blood glucose and insulin they are ideal for diabetic levels, reducing postprandial people. $\quad$ peaks and improving insulin sensitivity. All this makes legumes ideal foods for weight control.

They can help reduce the Dietary fiber is known for its risk of heart disease. participation in regulating LDL cholesterol levels, a recognized risk factor for coronary heart disease. 


\begin{tabular}{|l|l|}
\hline $\begin{array}{l}\text { They are a good source of } \\
\text { vitamins. }\end{array}$ & $\begin{array}{l}\text { The folate considerably } \\
\text { reduces the risk of congenital } \\
\text { anomalies of the neural tube, } \\
\text { such as spina bifida in } \\
\text { newborns. }\end{array}$ \\
\hline Protein content. & $\begin{array}{l}\text { The quality of proteins in } \\
\text { vegetarian and plant-based } \\
\text { diets improves considerably } \\
\text { when legumes are combined } \\
\text { with cereals. }\end{array}$ \\
\hline $\begin{array}{l}\text { They promote bone } \\
\text { health. }\end{array}$ & $\begin{array}{l}\text { Phytoestrogens can also } \\
\text { prevent cognitive decline } \\
\text { and reduce menopausal } \\
\text { symptoms. }\end{array}$ \\
\hline Legumes are gluten-free. & $\begin{array}{l}\text { Phytochemicals and } \\
\text { antioxidants may contain } \\
\text { antineoplastic properties. }\end{array}$ \\
\hline $\begin{array}{l}\text { They are rich in bioactive } \\
\text { compounds. }\end{array}$
\end{tabular}

Table 1 Benefits of legume consumption Source Consulted: Own Elaboration

According to the 2020 National Health and Nutrition Survey on Covid-19, the distribution of the average per capita expenditure on foods such as cereals, legumes and tubers, was $21.4 \%$ of the average expenditure on food. The average per capita expenditure for legumes is around 68.7 Mexican pesos (3.38 US dollars). During pandemia confinement, legumes were one of the food groups with greater consumption stability; $74.3 \%$ of the population maintained their consumption, while $14 \%$ increased and $11 \%$ decreased their consumption.

\section{Antinutritional Factors}

As mentioned earlier, legumes are considered whole foods since they contain proteins, carbohydrates, minerals, vitamins, among other nutritional components. However, they also present antinutritional factors (ANF) in their composition (Elizalde, et al., 2009) such as tannins, phytic acid, trypsin inhibitors, and flatulence-causing oligosaccharides (Khattab and Arntfield, 2009).

The term "antinutrients" is used to describe those compounds that can affect or cause a negative effect on the nutritional value of some foods, as well as on health because they hinder or inhibit the assimilation of some nutrients. ANF are considered non-fibrous natural substances, generated by the secondary metabolism of plants as a defense mechanism against stressful situations or the attack of molds, bacteria and birds (Elizalde, et al., 2009).
However, some ANF, due to their biological activities and when consumed in small amounts, have shown to be beneficial in the prevention of diseases (Rochfort and Panozzo 2007).

\section{Types of antinutritional factors}

\subsection{Tannins}

They are defined as versatile, astringent, and water-soluble phenolic compounds of high molecular weight ranging from $500 \mathrm{Da}$ to 3000 Da (Hassanpour, et al., 2011). It has been reported that tannins reduce the bioavailability of nutrients in the intestine (Idate, et al., 2021). Among the antinutritional effects of these compounds are reduced digestibility, mutagenic and carcinogenic effects, and the induction of hepatotoxic activity. The accumulation of tannins in legumes makes the protein unavailable and decreases the digestibility of the protein and most carbohydrates since amylases, lipases, trypsin, and chymotrypsin enzymes are inhibited by tannins (Idate, et al., 2021). The absorption of iron from the intestine can also be affected (Khattab and Arntfield, 2009).

\subsection{Saponins}

Saponins are compounds with a complex structure made of a hydrophobic steroidal nucleus and a hydrophilic part made of monosaccharide units. They largely determine the bitter taste of some foods (Elizalde, et al., 2009). Saponins are a category of steroidal glycosides that get their name from their ability to form stable, soap-like foams in aqueous solutions. Its intake through plant-based foods has been associated with both harmful and beneficial effects (Muzquiz, et al., 2012).

Saponins cannot be absorbed in the intestine, thus affecting the absorption of zinc and iron (Elizalde, et al., 2009). They have been found to reduce nutritional supply and the production of some digestive enzymes such as amylase, glucosidase, trypsin,chymotrypsin and lipase, which can cause indigestion-related health disorders, and the inhibition of bodily growth in animals (Idate, et al., 2021). 
These compounds decrease the intestinal uptake of some nutrients, such as glucose and cholesterol, through an intraluminal physicochemical interaction, for which it has been determined that they have a hypocholesterolemic activitydue to the formation of an insoluble complex with cholesterol, thus preventing its absorption in the intestine; in addition, they increase bile acid excretion, an indirect method of lowering cholesterol (Rochfort and Panozzo 2007). Its biochemical effects are due to the structural differences of its sapogenin fractions (Idate, et $a l ., 2021)$.They also have anti-cancer properties, inhibit dental cavities, and have been shown to have an inverse relationship with the incidence of kidney stones (Muzquiz, et al., 2012).

\subsection{Phytates}

Phytate is formed during the maturation of the plant's seeds; in dormant seeds it represents 60$90 \%$ of the total phosphate (Muzquiz, et al., 2012). Phytic acid hinders the activity ofenzymes, which are necessary for protein degradation in the small intestine and stomach also affect the bioavailability of minerals and has a strong effect on infants, pregnant and lactating women when large portions of cereal-based foods are consumed (Khattab and Arntfield, 2009).

It is present in small amounts in legumes and other food groups; its negative charge allows it to bind to some minerals such as iron, zinc, calcium, and magnesium, giving rise to an insoluble complex (Idate, et al., 2021). Phytate forms a strong complex with some proteins and resists their proteolysis. In general, the interaction of phytate with protein is dependent on $\mathrm{pH}$ and affect the protein structures that can hamper enzymatic activity, protein solubility and digestibility (Kumar, et al., 2010), modifies enzymatic activity with negative effects on the main digestive enzymes (lipase, $\alpha$-amylase, pepsin, trypsin and chymotrypsin) (Muzquiz, et al., 2012).

Phytate is the main form of phosphorus storage in legumes and other foods; it is known as a food inhibitor that chelates the micronutrient and prevents it from being bioavailable to monogastric animals, including humans because they lack the enzyme phytase in their digestive tract (Gupta, et al., 2015).
On the other side, a protective effect against a variety of cancers has been associated with phytate, mediated by antioxidant properties, interruption of cellular signal transduction and inhibition of the cell cycle. A therapeutic use against diabetes, atherosclerosis and coronary heart disease and the reduction of the formation of kidney stones has also been reported (Kumar, et al., 2010).

\subsection{Protease Inhibitors}

Protease inhibitors are thermolabile compounds that are present in legumes that inhibit the action of proteolytic enzymes (trypsin and chymotrypsin) causing alterations in the digestion (Elizalde, et al., 2009).

These compounds in research with animal models have been found to have negative health effects(Idate, et al., 2021), for example, some protease inhibitors have been associated with increased hypertrophy and hyperplasia of the pancreas, as well as with the hypersecretion of digestive enzymes (proteins rich in sulfur); causing a slowdown in growth, since the proteins of the seeds of legumes, are usually deficient in sulfur amino acids (Muzquiz, et al., 2012; Idate, et al., 2021).

However, these protease inhibitors have also been found to have tumor cell growth inhibitory activity and are considered a strategy in cancer therapy (Kim, et al., 2009; Clemente, et al., 2004).

\subsection{Lectines}

Lectines are considered as antinutritional factors since they are carbohydrate-binding proteins of non-immune origin that can recognize and bind simple or complex carbohydrates in a reversible and highly specific way (Lagarda, et al., 2017).

The main effect caused by lectins is related to the fact that they adhere to carbohydrates on the surface of the small intestine and cause damage to the intestinal wall in such a way that they affect the absorption and transport of some nutrients (Elizalde, et al., 2009).

In addition, the continuous secretion of gastric enzymes generates adverse health effects (gastric ulcers) that could cause a pathological disorder in the intestine (Idate, et al., 2021). 


\subsection{Cyanogenic Glucosides}

Cyanogenic glycosides have been found in more than 100 species in nature including legumes such as beans and chickpeas (Gleadow and Woodrow, 2002). They are derived from amino acids and are stored in vacuoles as inactive glycosylated precursors. The thermal processing of beans has been found to reduce total hydrogen cyanide content by $54-82 \%$ (Cressey, et al., 2013). Cyanogenic glycosides are not toxic by themselves, but cyanide is, acting at the level of cytochrome oxidase, a powerful inhibitor of the respiratory chain (Valle, 2000). In addition, after enzymatic hydrolysis by endogenous $\beta$ glucosidases they act as deterrents to feeding or oviposition (Shlichta, et al., 2014), and hydrogen cyanide is produced resulting in cyanide poisoning which causes rapid breathing, headache, dizziness and seizures, symptoms (Cressey, et al., 2013),

\subsection{Oxalates}

Oxalic acid is a strong organic acid that binds to minerals and forms insoluble salts of calcium and magnesium, reducing their intestinal absorption; in children it can lead to kidney damage after ingestion (Lluís, 1996). Oxalate is normally excreted in the urine, and can cause the formation of kidney stones due to its slow elimination (Valle, 2000). The ingestion of large amounts of oxalate can induce hyperoxaluria, which is a risk factor in the development of calcium oxalate stones (Siener, et al., 2020). Oxalate is present in different foods, and the normal dietary intake ranges from $80-10 \mathrm{mg} /$ day (Williams and Wandzilak, 1989). Its content in cooked legumes varies between $4-80 \mathrm{mg} / 100 \mathrm{~g}$; in beans, $50 \mathrm{mg}$ of oxalates are found per serving ( 1 cup), while lentils and chickpeas present contain 8 and 9mg / 100g, respectively (Chai and Liebman, 2005).

\section{Treatments for the reduction of antinutritional factors}

There are different processing methods and treatments that improve the nutritional quality of legumes by reducing the FAN content. It is important to mention that these compounds have beneficial functions in the plant, so genetic modification is not feasible (Khattab and Arntfield, 2009). Some technologies that reduce or eliminate ANF in legumes are explained below.

\subsection{Milling}

This is a traditional method used to remove the outer layer of the seeds (Nikmaram, et al., 2017). In this process the grains are ground into flour, and some ANF are eliminated (Samtiya, et al., 2020). However, it also removes important minerals present in food (Gupta, et al., 2015). Milling is used as a pretreatment, however, due to cellular degradation and the rearrangement of minerals, ANF and enzymes, the bioaccessibility of minerals is affected (Raes, et al., 2014).

One of the ANF eliminated through this method are phytates, since these are found in the aleurone, which is the outer coating of the endosperm (Nikmaram, et al., 2017).

\subsection{Soaking}

This technique, in addition to eliminating the ANF content, also reduces the cooking time of the legumes (Samtiya, et al., 2020). This process consists of placing the seeds in a solution of preferably acidified water at a certain temperature and for a period of time (Raes, et al., 2014). This processing method has been shown to reduce tannin and phytate content. Soaking caused a reduction of $42.82-48.91 \%$ in phytic acid content, a reduction of trypsin inhibitory activity of $10.22-19.85 \%$ and of oligosaccharides of $40 \%$ in legumes (Khattab and Arntfield, 2009). Specifically, in lentils, this method eliminated most of the oligosaccharides of the raffinose family (Valverde, et al., 1992).

\subsection{Cooking}

This is a method characterized by heat treatment of legumes in boiling water. This process elicits physicochemical changes as starch gelatinization, protein denaturation, polysaccharide solubilization, among others (Djabali, et al., 2020). Using this method in legumes has been shown to improve nutritional value due to the reduction of tannins, trypsin inhibitors, phytates, among others (Samtiya, et al., 2020; Wang, et al., 2009).

For example, cooking inactivates trypsin inhibitors by denaturation; previous research has shown that cooking beans for 60 minutes completely removes trypsin inhibitors (Khattab and Arntfield, 2009). 
A reduction in tannins has also been observed in beans (Idate, et al., 2021). Boiling removes oligosaccharides that cause flatulence; when this is carried out without a previous soaking of the seeds, the level of total soluble sugars increases (Valverde, et al., 1992). In lentils, as well as in beans, broad beans, chickpeas, cooking eliminates or reduces the trypsin inhibitory activity, as well as the phytic acid content (Wang, et al., 2009; Ma, et al., 2011).

\subsection{Germination}

This method, like the previous ones, also improves the nutritional quality of legumes; it consists of soaking the seeds in water, which will activate the sequence of biochemical reactions that involves the germination process, until the elongation of the embryonic axes. The process includes soaking, draining, and leaving the seeds until they germinate and begin to sprout (Raes, et al., 2014).

Germination activates the phytase, an enzyme that degrades phytate leading to a decrease in phytic acid concentrations (Samtiya, et al., 2020). This process is considered one of the best options for the preparation of chickpea because it also increases the number of phenolic compounds (Idate, et al., 2021).

\subsection{Dehulling}

This technique consists of the removal of the outer layers of the seeds and is often used as a pretreatment for other methods (Raes, et al., 2014). Dehulling reduces the cooking time of legumes by eliminating the impermeable layer of the seed, which prevents water absorption (Wang, et al., 2009).

This method has a great impact on the elimination of fibers, tannins and other phenolic compounds that fix iron (Raes, et al., 2014). It also decreases trypsin inhibitory activity in different varieties of lentils, although to a lesser extent than cooking (Wang, et al., 2009), and removes minerals as well (Raes, et al., 2014).

\section{Conclusions}

Legumes are complete foods that are characterized by their high protein content, in addition to other nutrients such as carbohydrates, minerals, vitamins, among others; however, they contain ANF, which cause a negative effect on the nutritional value of this food group, as well as on health because they hinder or inhibit the assimilation of some nutrients. For this reason, it is necessary to increase the knowledge on processing methods or techniques that might reduce or eliminate these components in each legume, without affecting the nutritional quality of the food.

\section{References}

Chai, W., \& Liebman, M. (2005). Oxalate content of legumes, nuts, and grain-based flours. Journal of Food Composition and Analysis, 18(7), 723-729. doi:10.1016/j.jfca.2004.07.001.

Clemente A, Mackenzie DA, Johnson IT, Domoney C (2004). Investigation of legume seed protease inhibitors as potential anticarcinogenic proteins. In: Muzquiz M, Hill GD, Pedrosa MM, Burbano C (eds) Proceedings of the fourth international workshop on antinutritional factors in legume seeds and oilseeds. EAAP publication No. 110, Wageningen, pp 137-142.

Cressey, P., Saunders, D., \& Goodman, J. (2013). Cyanogenic glycosides in plant-based foods available in New Zealand. Food Additives \& Contaminants: Part A, 30(11), 1946-1953. doi:10.1080/19440049.2013.825819.

Djabali, S. \& Makhlouf, F.Z. \& Ertaş, Abdulselam \& Barkat, Makeesha. (2020). Effect of heat treatment on polyphenolic compounds and antioxidant activity of lentils (Lens culinaris). Acta Scientifica Naturalis. 7. 58-71. 10.2478/asn-2020-0033.

Elizalde, A., Pismag, Y., \& Chaparro, D. (2009). FACTORES ANTINUTRICIONALES EN SEMILLAS. Biotecnología en el Sector Agropecuario y Agroindustrial, 7(1), 45-54.

Gleadow RM, Woodrow IE (2002) Constraints on effectiveness of cyanogenic glycosides in herbivore defense. J Chem Ecol 28:1301-1313. 
Gupta, RK, Gangoliya, SS \& Singh, NK Reducción del ácido fítico y mejora de los micronutrientes biodisponibles en los cereales alimentarios. J Food Sci Technol 52, 676-684 (2015). https://doi.org/10.1007/s13197-0130978-y.

Hassanpour, S., MaheriSis, N., \& Eshratkhah, B. (2011). Plants and secondary metabolites (Tannins): A Review. Int. J. Forest, Soil and Erosion, 1 (1), 47-53.

Idate, A., Shah, R., Gaikwad, V., Kumathekar, S., \& Temgire, S. (2021). A comprehensive review on antinutritional factors of chickpea (Cicer arietinum L.). The Pharma Innovation Journal, 10(5), 816-823.

Khattab, R. Y., \& Arntfield, S. D. (2009). Nutritional quality of legume seeds as affected by some physical treatments 2 . Antinutritional factors. LWT - Food Science and Technology, 42(6), 1113-1118. doi:10.1016/j.lwt.2009.02.004.

Kim, J.-Y., Park, S.-C., Hwang, I., Cheong, H., Nah, J.-W., Hahm, K.-S., \& Park, Y. (2009). Protease Inhibitors from Plants with Antimicrobial Activity. International Journal of Molecular Sciences, 10(6), 2860-2872. doi:10.3390/ijms10062860.

Kumar V, Sinha AK, Makkar HPS, Becker K. Dietary roles of phytate and phytase in human nutrition: A review. Food Chemistry, 2010; 120(4):945-959.

Lagarda, I., Guzman, A., \& Vazquez, L. (2017). Legume Lectins: Proteins with Diverse Applications. International Journal of Molecular Sciences, $18(6), \quad 1242$. doi:10.3390/ijms18061242.

Lluís Berdonces, Josep. (1996). Toxicología alimentaria. Natura Medicatrix: Revista médica para el estudio y difusión de las medicinas alternativas, ISSN 0212-9078, No .44 (Otoño), págs. 16-20.

Ma, Z., Boye, J. I., Simpson, B. K., Prasher, S. O., Monpetit, D., \& Malcolmson, L. (2011). Thermal processing effects on the functional properties and microstructure of lentil, chickpea, and pea flours. Food Research International, 44(8), 2534-2544. doi:10.1016/j.foodres.2010.12.017.
Muzquiz, M., Varela, A., Burbano, C., Cuadrado, C., Guillamón, E., \& Pedrosa, M. M. (2012). Bioactive compounds in legumes: pronutritive and antinutritive actions. Implications for nutrition and health. Phytochemistry Reviews, 11(2-3), 227-244. doi:10.1007/s11101-012-9233-9.

Nikmaram, N., Leong, S. Y., Koubaa, M., Zhu, Z., Barba, F. J., Greiner, R., ... Roohinejad, S. (2017). Effect of extrusion on the anti-nutritional factors of food products: An overview. Food Control, 79 , 62-73. doi:10.1016/j.foodcont.2017.03.02.

Organización de las Naciones Unidas para la alimentación y la Agricultura (FAO). Beneficios nutricionales de las legumbres. 2016. Disponible es:

http://www.fao.org/fileadmin/user_upload/puls es2016/docs/factsheets/Nutrition_SP_PRINT.p df.

Raes, K., Knockaert, D., Struijs, K., \& Van Camp, J. (2014). Role of processing on bioaccessibility of minerals: Influence of localization of minerals and anti-nutritional factors in the plant. Trends in Food Science \& Technology, 37(1), 32-41.

Rochfort, S., \& Panozzo, J. (2007). Phytochemicals for Health, the Role of Pulses. Journal of Agricultural and Food Chemistry, 55(20), 7981-7994. doi:10.1021/jf071704w.

Samtiya, M., Aluko, R. E., \& Dhewa, T. (2020). Plant food anti-nutritional factors and their reduction strategies: an overview. Food Production, Processing and Nutrition, 2(1). doi:10.1186/s43014-020-0020-5.

Secretaría de Agricultura y Desarrollo Rural. (13 de Octubre de 2015). GOBIERNO DE MÉXICO. Obtenido de Leguminosas, el alimento de todos: https://www.gob.mx/agricultura/es/articulos/leg uminosas-el-alimento-de-todos.

Shamah-Levy T, Romero-Martínez M, Barrientos-Gutiérrez T, Cuevas-Nasu L, Bautista-Arredondo S, Colchero MA, GaonaPineda EB, Lazcano-Ponce E, MartínezBarnetche J, Alpuche-Arana C, RiveraDommarco J. Encuesta Nacional de Salud y Nutrición 2020 sobre Covid-19. Resultados nacionales. Cuernavaca, México: Instituto Nacional de Salud Pública, 2021. 
Shlichta, J. G., Glauser, G., \& Benrey, B. (2014). Variation in Cyanogenic Glycosides Across Populations of Wild Lima Beans (Phaseolus lunatus) Has No Apparent Effect on Bruchid Beetle Performance. Journal of Chemical Ecology, 40(5), 468-475. doi:10.1007/s10886014-0434-0.

Siener, R., Seidler, A., \& Hönow, R. (2020). Oxalate-rich foods. Food Science and Technology, 41, 169-173.

Valle-Vega, P., \& Lucas-Florentino, B. (2000). Toxicología de alimentos. México, DF: Instituto Nacional de Salud Pública. Centro Nacional de Salud Ambiental. Retrieved from http://cetis59.com/biblioteca/toxicologia.pdf.

Valverde, C., Frías, J., \& Valverde, S. (1992). Effect of Processing on the Soluble Carbohydrate Content of Lentils. Journal of Food Protection, 55(4), 301-303. doi:10.4315/0362-028x-55.4.301.

Wang, N., Hatcher, D. W., Toews, R., \& Gawalko, E. J. (2009). Influence of cooking and dehulling on nutritional composition of several varieties of lentils (Lens culinaris). LWT - Food Science and Technology, 42(4), 842-848. doi:10.1016/j.lwt.2008.10.007.

Williams, H.E., Wandzilak, T.R., 1989. Oxalate synthesis, transport and the hyperoxaluricsyndromes. Journal of Urology 141, 742-747. 